\title{
KNOWLEDGE ECONOMY CONCEPTS AND ROLES IN PERSPECTIVES OF UNIVERSITY TEACHERS OF ASIAN AND EUROPEAN STATES
}

\author{
Saghir Ahmad ${ }^{1}$, Ayesha Batool ${ }^{2}$, Sadaf Iqbal ${ }^{3}$, Manzoor Hussain Shah $^{4}$
}

${ }^{1,3}$ Department of Education, Hazara University Mansehra, Pakistan; ${ }^{2 *}$ Assistant Professor, Lahore College for Women University Lahore, Pakistan; ${ }^{4}$ Dean Faculty of Arts and Humanities, Chairman, Department of Education, Hazara University Mansehra KP, Pakistan.

Email: ${ }^{1}$ saghir.edu786@gmail.com, ${ }^{2 *}$ drayesharana19@gmail.com

\author{
Article History: Received on $2^{\text {nd }}$ June 2021, Revised on $6^{\text {th }}$ June 2021, Published on $7^{\text {th }}$ June 2021
}

\begin{abstract}
Purpose of the study: The study aimed to identify knowledge economy concepts and roles in perspectives of university teachers of Asian and European States and examine the relationship between knowledge economy concepts and roles of university teachers.

Methodology: This study was quantitative correlation and survey type in nature. The study population was public sector universities teachers of three countries (Pakistan, United Kingdom, and India). Six public universities were included in the population. From population one hundred and eighty teachers selected as a sample of study conveniently.

Main Findings: Teachers agree unanimously that human beings are knowledge capital because they generate new knowledge with innovative ideas and conducting researches in different fields. Humans are the source of producing and placement of knowledge excellently and professionally. There is a strong path relationship $r=.8$ between knowledge economy concepts of teachers and their roles regarding this. Findings showed that there was a significant difference in teachers' conceptions of Pakistan and the United Kingdom.
\end{abstract}

Applications of this study: The teachers may make clear conceptions about the knowledge economy and recognize their roles to produce innovative and skills-oriented human resources and data to strengthen the knowledge-based economy.

Novelty/Originality of this study: The knowledge economy is a new concept itself in this context. University teachers' of three different countries highlighted concepts and roles about the knowledge economy.

Keywords: Knowledge-Economy, Concepts, Roles, University Teachers, Skills, Asian and European States.

\section{INTRODUCTION}

University education plays a crucial role in developing nations and their economies financially as well as knowledgeable. It has a significant nature in creating networks and their economy, as it contributes to conduct research, produce knowledge, and providing new information through instructing, logical, innovative work. Universities are also involved in sustainable development, human capital, and a knowledge-oriented economy in a society. Higher education leads organizations in terms of knowledge, economically, and human resources growth. Without it, people are unable to grow and compete in knowledge and economic sectors (Ameen, 2020; Arab Knowledge Index, 2015). The progress to the information economy is a universal marvel seen to possess learning. Economy implies the capacity to enhance and make scholarly items that the market thinks nothing about it. It is a vulnerable economy and in this way that possesses knowledge and learning is predominant. Moreover, a knowledge-oriented economy considers inventiveness to be the establishment stone where consideration is given to the idea instead of crude materials and human exertion (Brinkley, 2014; Oluwadare, 2015; Salman, 2009).

The significance of a knowledge-based economy originated from its job in psychological information and the new technological innovation, which was created and delivered quickly in various fields (Khalaf, 2007). In like manner, it supports dispersion, utilizing and creating information without restriction. It accomplishes electronic trade and rolls out an improvement in the old occupations. It helps the universities in advancement and inventiveness (Hashimi \& Azawi, 2010; Safi et al., 2010). The capital is proficient at making, claiming, and utilizing knowledge and learning. Higher education is one of the elements of the knowledge economy (Moiseev, et al., 2019).

Teachers in the knowledge economy ought to have principle abilities: the particular and precise logical specialization and the mental and instructive recovery of educating and directing students (Lavergne, 2004). Teachers' responsibility in the time of information economy could be abridged by two things: to ensure that the learner gains the knowledge and information which means building up capacities to empower him to engage in various subjects of information and this is conceivable if the incredible progress of learning towards economy execution is spoken to by-laws for educating. At the same time, the other one is the need to have the educator as the impact factor in the instructing and learning process, which implies that the educator needs to proliferate the knowledge arrays that he had some expertise in and to be trained for teaching them also (Bonal \& Ramba, 2003).

It is observed as the primary centre to go into the information age and to create analytical research further to upgrading advancement, data innovation, media transmission, proceeding with training, and network organization. Research is one 
of the substantial elements of higher education (Connell, 2015; Juma, 2009). So, it is compulsory to observe the advancement of higher institutes specifically from their conventional role into the knowledge economy period to get their robust investment in their going into the learning economy age. New knowledge is fruitful in the sense of the employment market and, it quickly ends up inappropriate to stay aware of the prerequisites of the knowledge stage of development. The knowledge economy is elaborated with the latest information, innovation advancement, decreasing geological obstructions and rivalry, and develops resources (Abu Al-Humos, 2006).

University teachers have different responsibilities to enrich the knowledge economy. Their performance and skills in the education economy are ever more sustainable in getting ready and making arrangements for education. They start considering what learners should know and what should be possible. Thus, the instructor turns into an essential and critical thinker, who stays away from retention, helps others, and utilizes relevant teaching material (Abu-Nair et al., 2011; Frunzaru, et al., 2018). Ideal teachers must have essential abilities in the knowledge economy phase at a similar time. They need to be experts in their relevant subjects. They should be psychologically strong, and their level of qualification may be enough to supervise and instruct students efficiently (Batarsah, 2005; UNESCO, 2015; World Bank, 2008).

Moreover, the period of knowledge economy demands specific qualities that teachers must have; they produce new knowledge and different resources for sustainable development and can make students familiar with the knowledge economy in the prompt condition of the university and everywhere throughout the world. He ought to have the ability to assist normal and disabled learners, to make psychological and social aptitudes that are vital in the twenty-first century. For example, openness and critical thinking, utilizing data to construct logical pattern and view towards the problem, phoneme or issue, while understanding the way of life and sustaining it (Al-Hashimi \& Al-Azawi, 2009). To understand world philosophy, values and managing them emphatically without narrow-mindedness or inclination, all are keeping their social personality and the availability to the world values at a time. Furthermore, faculty members must be familiar with the teaching methods, utilizing technology, multimedia, and assessment evaluation techniques. The educator ought to be a social and logical role model for his learners, facilitator of getting knowledge, liable to students' development and growth. He motivates them as an ideal teacher. However, the higher education teacher needs institution condition recognizes advancing the activities that expect to fabricate learning economy. Universities play a significant role in the development of information and knowledge-based economy (Salem, 2014).

Krishnaswami (2015) represented research related to traditional knowledge to the knowledge economy in Indian universities. Results of the study follow the underlying foundations of Indian instruction as a rule and advanced education, specifically through the ages and the progressions achieved with and without the country's responsibility. Especially, university education confronted many difficulties in defying snags that have been being made in thought the political, social, and monetary resources. Knowledge economy from higher education administration and leadership is research-based and information prerequisites are pursued with the prerequisites identified with education planning (Thalgi, 2020).

Awajneh et al. (2017) directed three studies related to the knowledge economy and university teachers that give a challenge in general and university education to stay aware of advancement and worldwide progress and improvement just to give inspiration of education field. Findings of a single subject and focus group interviews also showed that knowledge information economy rules experienced by instructors are focused on teaching methods and faculty roles and role of students to produce knowledge to strengthen the learning economy. Teachers know their roles about knowledge economy but performing moderately. They need the training to perform more in the context of the knowledge economy to compete in the world. It is also their vital role as researchers (Ahmad, 2016; La Rue, 2005).

\section{RATIONALE AND SIGNIFICANCE OF THE STUDY}

The teacher is one of the main ingredients of the academic structure. There is a need to re-evaluate his duties or jobs in the period of the knowledge economy, whether it was in the Asian or European world. It is indicated there are gaps between what the instructive frameworks have accomplished and between what the territory needs to achieve its present and future advancement objectives. Like this, the educator's training with regards to the new jobs in light of knowledge and learning economy is viewed as one of the essential components that help the training procedure to succeed. Therefore, the present study established to know the concepts and roles of teachers and check the relationship between variables in the field of the knowledge economy. The significance of the topic which the research tended to tries to build up information economy, particularly in the academic field for tackling challenges. Organize and present a suitable portrayal to establish a faculty role in the shadow of the knowledge economy, which aids in raising the educator's competency and improving his instructing level. The study results are fruitful to universities and Higher Education Commission regarding concepts about the knowledge economy, and their roles have to know in knowledge economy context and developing appropriate programs to train teaching faculty.

\section{RESEARCH OBJECTIVES}

The study was conducted to achieve the following objectives:

1. Identify knowledge economy concepts and roles in perspectives of university teachers of Asian and European States. 
2. Examine the relationship between knowledge economy concepts and roles of university teachers of different countries.

3. To check the construct reliability and validity of knowledge economy concepts and roles scales.

4. To check the difference in teachers' perceptions regarding knowledge economy concepts and roles in terms of demographic variables.

\section{METHODOLOGY}

There are various ways for conducting research as well as several sorts of research. Empirical investigations necessitate a precise approach, which adds to their worth and validity. The efficiency of a study is determined by its methodology, which outlines the approach and method in detail.

\section{RESEARCH DESIGN}

This study was quantitative correlation and survey type in nature.

\section{POPULATION AND SAMPLING}

The study population was public sector universities teachers of three countries (Pakistan, United Kingdom, and India). Six public universities (two from each country) were included in the population. From the population, one hundred and eighty teachers were readily chosen as a study sample. It was challenging to choose a sample at random because the nature of the sample required approaching participants from across the country and around the world who were not easily accessible or local.

\section{INSTRUMENTATION}

It is regarded as the foundation of any research project. Without a valid instrument, researchers are unable to perform the study. On a five-point Likert scale, a questionnaire was used to collect pertinent information from participants about knowledge economy principles and teaching duties. Without professional input, the research instrument is ambiguous and unreliable. As a result, field specialists verified the scale. After that, the method of pilot testing was used to assure reliability. Cronbach's Alpha was used to ensure that the internal consistency of the items was confirmed.

\section{DATA COLLECTION PROCEDURE}

Collecting data from national and international participants was a difficult task. It requires a significant amount of energy, time, and financial resources. Researchers approached teachers by the use of electronic mail. Their mail ids were explored through websites searching of relevant universities. An online questionnaire link was sent to them; they filled it and submitted it electronically.

\section{ETHICAL CONSIDERATIONS}

They were briefed that this information will be used only for research purposes. All subjects of the study who participated showed cooperative behaviour. They are highly obliged by researchers because without their participation, we were unable to conduct this study effectively.

\section{DATA ANALYSIS}

Researchers, on the other hand, put in a lot of work to perform this study, particularly in the data-gathering technique, and it was a success. Data collecting is only the first step; managing or handling data in a methodical manner is a more difficult and time-consuming undertaking. Data were analyzed by using SPSS, in which descriptive and inferential statistical techniques were applied and for structural equation modelling, SmartPLS software was used. Path relationship established of knowledge economy concepts and roles of university teachers. Mean scores, standard deviations, Pearson $r$, Path relationship, $r$ square, construct validity and reliability, bootstrapping, independent samples t-test, and one-way ANOVA were used. A detailed data analysis is being carried out.

\section{RESULTS/FINDINGS}

Table 1: Reliability of Scales

\begin{tabular}{lcc}
\hline Factors & Alpha values & No. of Items \\
\hline Knowledge-Economy Concepts & .924 & 13 \\
\hline Knowledge-Economy Roles & .941 & 19 \\
\hline
\end{tabular}

The questionnaire consisted of two factors; knowledge economy concepts and roles. There were total the thirty-two items. The first variable knowledge economy concepts consisted of 13 items, and 19 statements described the roles of teachers in the knowledge economy. Cronbach's Alpha was applied to ensure items reliability. The alpha values were .924 and .941 , respectively which are statistically significant and highly acceptable. It showed that there is internal consistency among items, and statements are positively correlated with each other. 

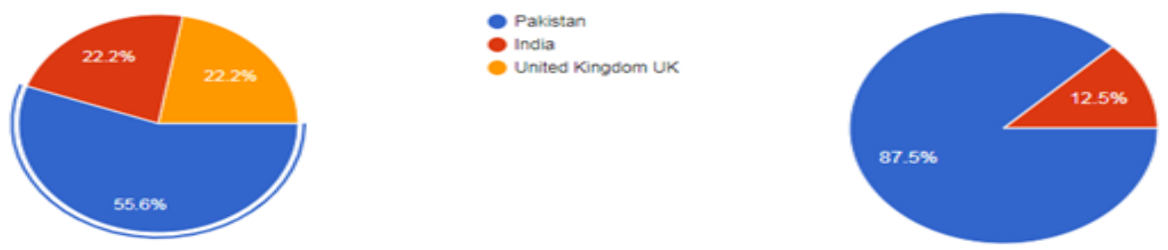

Public
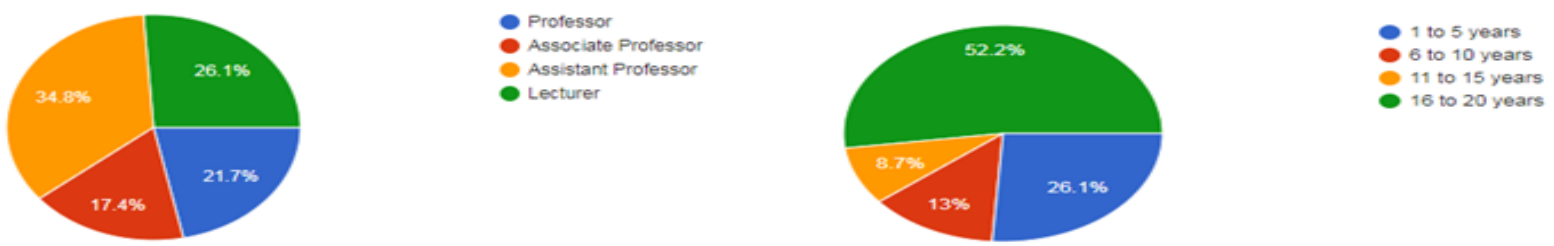

Figure 1: Demographic information about sample of the study

It shows the data of the selected sample of the study. Teachers of three states from public and private universities participated in this study, which was a lecturer to professor. They had teaching experience from range one to more than twenty years in this profession.

Table 2: Knowledge-Economy Concepts

\begin{tabular}{llll}
\hline Items & $\boldsymbol{M}$ & $\boldsymbol{S D}$ & Verdict \\
\hline Human is capital & 4.30 & .722 & Agree \\
\hline Deployment of knowledge & 4.48 & .654 & Agree \\
\hline Technology & 4.15 & .755 & Agree \\
\hline Improving life quality & 4.43 & .651 & Agree \\
\hline Equal distribution & 3.85 & 1.005 & Agree \\
\hline Sustainable development & 4.48 & .687 & Agree \\
\hline Abilities utilization & 4.11 & .895 & Agree \\
\hline Education and training & 4.28 & .830 & Agree \\
\hline Knowledge meets values & 4.17 & .820 & Agree \\
\hline Understanding knowledge and human capital & 4.35 & .670 & Agree \\
\hline Learning to produce knowledge & 4.41 & .682 & Agree \\
\hline Individuals lifelong & 4.59 & .682 & Agree \\
\hline Research and development & 4.11 & .733 & Agree \\
\hline
\end{tabular}

Table shows mean scores regarding different concepts of the knowledge economy and university teachers' verdict, which they gave in this context. They were agreed that human beings are considered knowledge capital because they generate new knowledge with innovative ideas and conducting researches in different fields. Humans are the source of producing and placement of knowledge excellently and professionally. They utilize information and develop new technology. Technology helps out human beings to know more in less time. The economy that focuses on gaining knowledge plays the leading role to improve life quality in all areas. They said knowledge economy provides equal and fair delivery of human capabilities. Teachers were strongly agreed that it develops human capital and building sustainable development. Individuals take part in technical and scientific researches. They utilize their different skills and abilities to bringing into being new knowledge. They also stated education and training both are the basic requirement of the knowledge economy. They highlighted only values-oriented knowledge is part of this economy. If knowledge is value-free, then it's no place in the knowledge economy. Thus, knowledge should meet the norms and values of a particular society. A group of teachers have a deep understanding of the role of knowledge and human capital. They are busy to think progressive ideas and learn new things for the sake of knowledge production. The majority of them said they produced educated people throughout their lives. They also agreed with everything that allied to the economics of knowledge practices itself for conducting research and development activities. It is concluded that most of the teachers have clear knowledge economy concepts.

Table 3: Knowledge-Economy Roles

\begin{tabular}{llll}
\hline Items & $\boldsymbol{M}$ & $\boldsymbol{S D}$ & Verdict \\
\hline Willingness social work & 4.28 & .830 & Agree \\
\hline Negotiate and discuss & 4.35 & .601 & Agree \\
\hline Leading skills & 4.54 & .582 & Agree \\
\hline Justice and equality & 4.50 & .584 & Agree \\
\hline Critical thinking & 4.46 & .686 & Agree \\
\hline Friendly with students & 4.67 & .557 & Agree \\
\hline
\end{tabular}




\begin{tabular}{lccl}
\hline Facilitator of learning & 4.72 & .580 & Agree \\
\hline Leader and creative & 4.50 & .584 & Agree \\
\hline Role Model & 4.11 & .791 & Agree \\
\hline Plan things systematically & 4.28 & .617 & Agree \\
\hline Improving qualifications and skills & 4.50 & .655 & Agree \\
\hline Innovation and challenging & 4.28 & .716 & Agree \\
\hline Monitor and guide & 4.33 & .665 & Agree \\
\hline Transformer moral values & 4.20 & .829 & Agree \\
\hline Learn new things & 4.46 & .619 & Agree \\
\hline Emotionally strong & 4.07 & .849 & Agree \\
\hline Source knowledge wealth & 4.02 & .926 & Agree \\
\hline Good Researcher & 4.11 & .845 & Agree \\
\hline Cooperative behavior & 4.41 & .928 & Agree \\
\hline
\end{tabular}

This table indicates the knowledge economy roles of teachers that how well aware they are, and how they play their roles in the knowledge economy. Most of them agreed they show readiness in social activities. They can negotiate and discuss different topics for learning. Mean score shows they have the skills to lead the class and instruct students. They play roles by showing justice and equality characteristics. Critical thinking plays a vital role in the knowledge economy. Teachers said they practice and use critical thinking while teaching the class as well as in research activities. They treat students in a friendly environment and support them where they demand. Therefore, teachers have loyal and friendly behaviour with students. The majority of them said they are facilitators of learning. They compensate the new generation with the latest knowledge in their relevant subjects. Teachers have creative minds. They said they lead with innovative and creative ideas because these are basic to become role model of learners. Every teacher tries that students follow him as a role model. They plan lectures and different activities step by step and systematically. Most of the teachers said they are busy improving qualification level and specific skills with time. They play a role to monitor and guide students. They play a crucial role in the knowledge economy while transforming civilization basis, norms, and moral values to the next generation. They agreed they can learn new things. They are emotionally intense and disagree with others just to gain knowledge and for good researchers. A group of them said they have supportive behavior with colleagues. Therefore, university teachers are playing different roles in the knowledge economy comprehensively.

Table 4: Relationship between Knowledge-Economy Factors

\begin{tabular}{llc}
\hline Factors & $\boldsymbol{r}$-value & Sig. \\
\hline Knowledge-Economy Concepts and Roles & $.765^{* * *}$ & .000 \\
\hline
\end{tabular}

The table shows that there is a strong statistically significant relationship $r=.765^{* *}$ between teachers' knowledge economy concepts and roles. It seems that teachers have an understanding of the knowledge economy, and they know the roles which they play and have to play for the knowledge economy. Those teachers who understand the knowledge economy concepts may play different fruitful roles to upgrade the knowledge economy. There is a positive correlation between the two variables.

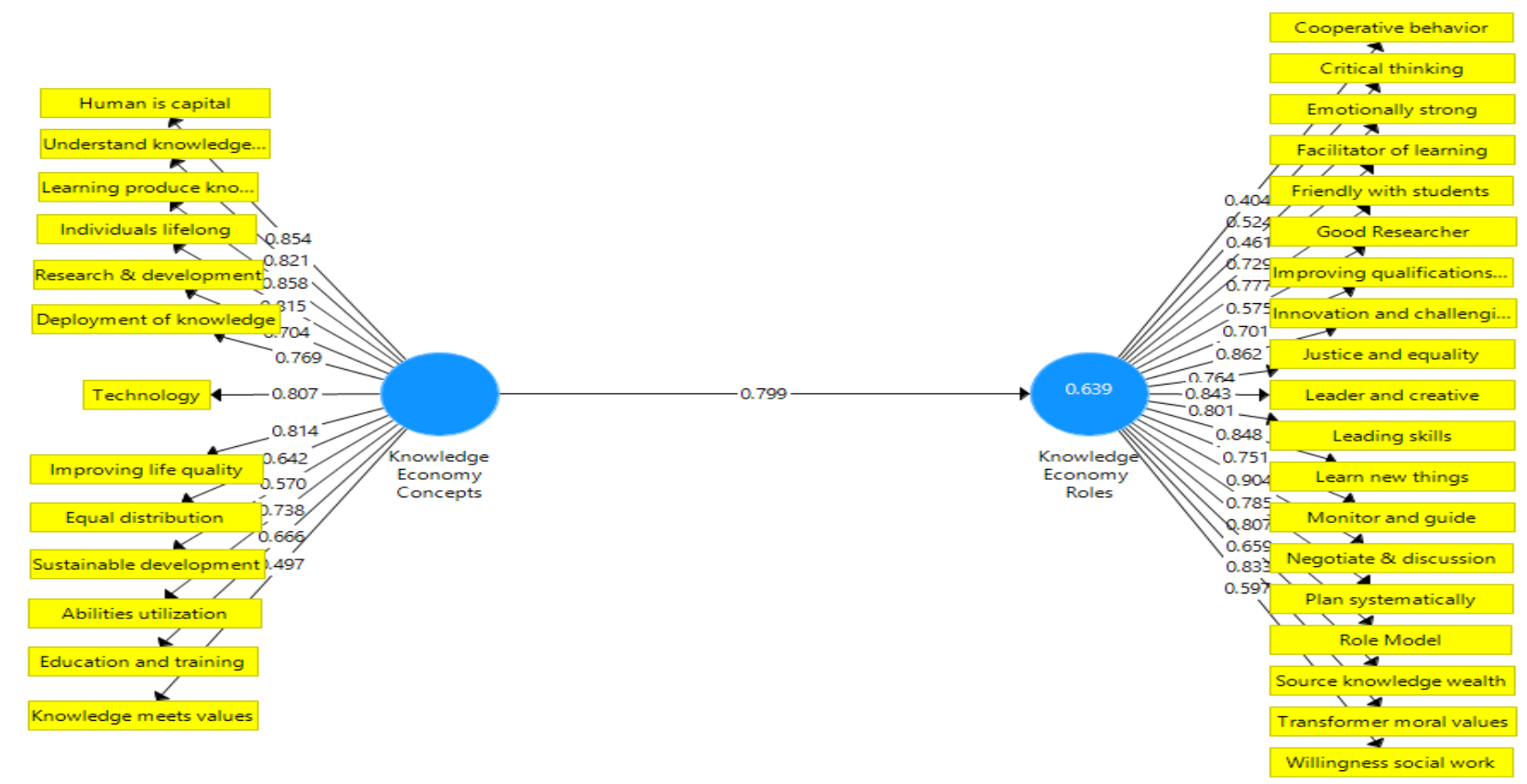

Figure 2: Path relationship between knowledge economy concepts of teachers and roles 
The above figure is related to the path relationship. There are two main factors in blue circles namely, knowledge economy concepts and economy roles. Items loadings of both dimensions are in yellow boxes. It shows that there is a strong path relationship $r=.8$ between knowledge economy concepts of teachers and their roles regarding this. All statements of both factors in yellow boxes almost have a ranged from value .5 to above .9 . It means items are interrelated and highly significant. It also shows all statements are necessary to measure both factors, knowledge economy concepts and economy roles.

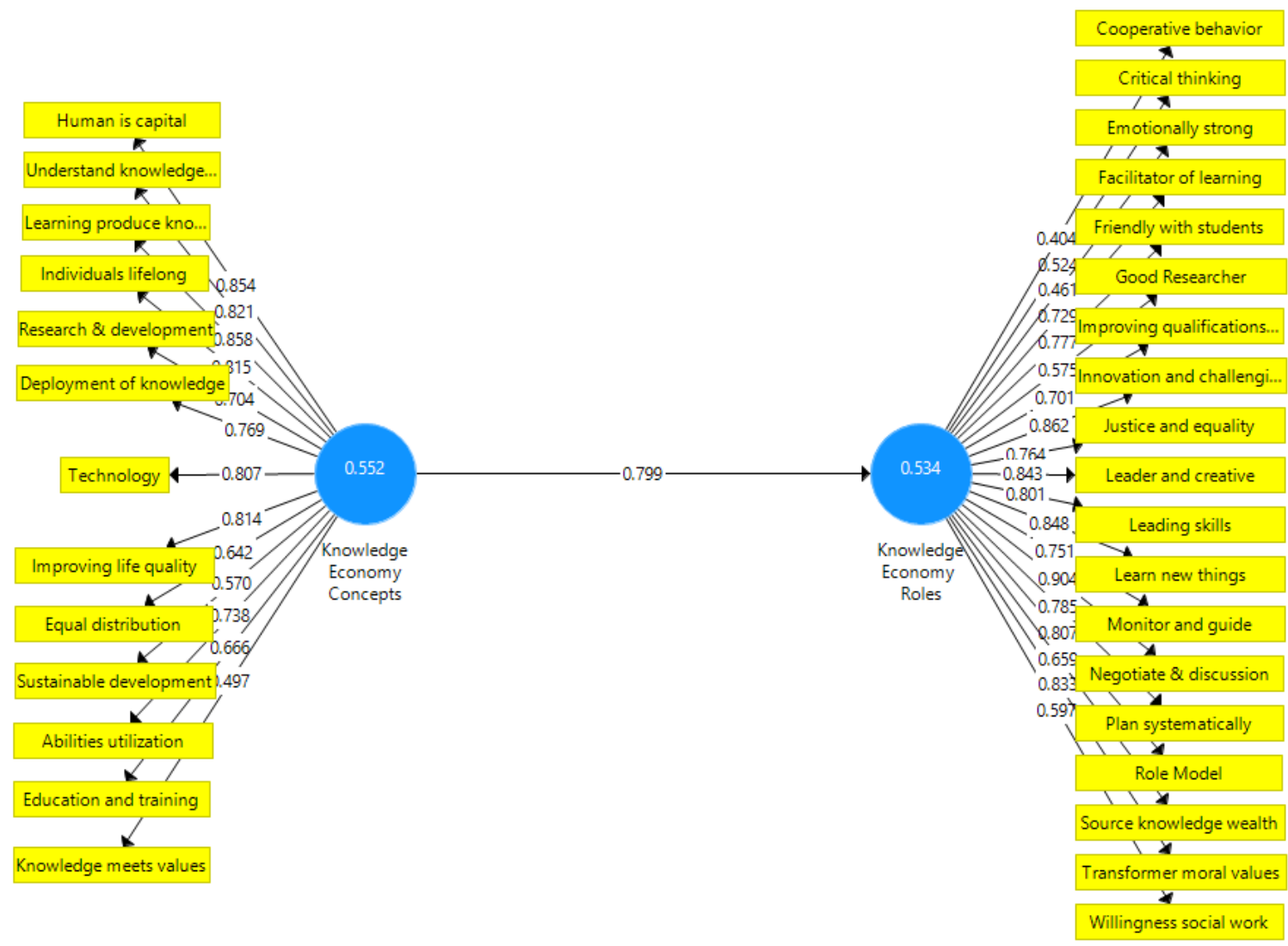

Figure 3: Path average relationship between variables

This figure contains moderate variance path association between knowledge economy concepts of teachers and roles. Both variables are strongly interrelated positively. If teachers know knowledge economy concepts, then they can easily play their roles in the knowledge economy.

\section{Construct Reliability and Validity}

\begin{tabular}{|c|c|c|c|c|c|c|c|}
\hline \multirow[t]{2}{*}{ Matrix } & 㩰萃 Cronbach's Alpha & 掉望 rho_A & & Composite Reliability & 接萃 Average Varian & extracted (AVE) & \\
\hline & & \multicolumn{2}{|c|}{ Cronbach's Alpha } & rho_A & Composite Reliability & \multicolumn{2}{|c|}{ Average Variance Extracted (AVE) } \\
\hline \multicolumn{2}{|c|}{ Knowledge Economy Concepts } & \multicolumn{2}{|c|}{0.929} & 0.941 & 0.940 & & 0.552 \\
\hline \multicolumn{2}{|c|}{ Knowledge Economy_Roles } & \multicolumn{2}{|c|}{0.948} & 0.957 & 0.954 & & 0.534 \\
\hline
\end{tabular}

Figure 4: Construct reliability and validity

The validity and reliability of a scale are both confirmed, it is deemed accurate and valid. Structural equation modelling examined construct reliability and validity in path analysis, as shown in the diagram above. Four distinct tests were used to determine reliability and validity. Cronbach's Alpha, rho A, composite reliability, and average variance were all calculated. The green reliability scores indicate that the scales of knowledge economy concepts and roles are highly substantial, consistent, and trustworthy. Ahmad and Hussain (2019) stated that the green color of values showed satisfactory and significant consistency among scales items. All values are competing with the threshold in this figure. Thus, these values are above than marginal line, due to which these numbers are in green colour.

Table 5: Gender Difference in Teachers' Concepts and Roles about Knowledge-Economy

\begin{tabular}{llllll}
\hline Factors & Gender & $\boldsymbol{M}$ & $\boldsymbol{S D}$ & $\boldsymbol{t}$ & Sig. \\
\hline Knowledge-Economy Concepts & Male & 54.13 & 7.749 & -3.508 & .001 \\
\hline
\end{tabular}




\begin{tabular}{llllll}
\hline & Female & 58.69 & 4.680 & & \\
\hline Knowledge-Economy Roles & Male & 80.90 & 10.018 & -2.691 & .008 \\
\cline { 2 - 6 } & Female & 86.31 & 7.350 & & \\
\hline
\end{tabular}

Table shows that independent samples t-test was used to check the difference in male and female teachers' concepts and roles related to the knowledge economy. There was a statistical difference in their concepts $-3.508, p=.01$ and roles $2.691, p=.08$ regarding knowledge economy at significance level $p \geq .05$. It means that teachers have different perceptions regarding concepts and roles due to gender differences.

Table 6: States Difference in Teachers' Concepts and Roles about Knowledge-Economy

\begin{tabular}{llllll}
\hline Factors & States & $\boldsymbol{M}$ & $\boldsymbol{S D}$ & $\boldsymbol{F}$ & Sig. \\
\hline Knowledge-Economy Concepts & Pakistan & 53.55 & 7.550 & 4.416 & .015 \\
\cline { 2 - 6 } & UK & 58.29 & 7.112 & & \\
\cline { 2 - 6 } & India & 56.90 & 4.689 & & \\
\cline { 2 - 6 } & Total & 55.72 & 7.152 & & \\
\hline Knowledge-Economy Roles & Pakistan & 81.27 & 10.531 & 2.091 & .13 \\
\cline { 2 - 6 } & UK & 85.79 & 9.492 & & \\
\cline { 2 - 6 } & India & 81.90 & 5.794 & & \\
\cline { 2 - 6 } & Total & 82.78 & 9.497 & & \\
\hline
\end{tabular}

One-way ANOVA was applied to check the country difference in teachers' concepts and roles in the knowledge economy. There was a difference in teachers' concepts $4.416, p=.01$ of different states regarding knowledge economy but was no difference in their roles $2.09, p=.13$ at significance level $p \geq .05$.

Table 7: Post Hoc for States Difference in Teachers' Concepts about Knowledge-Economy

\begin{tabular}{llllll}
\hline Dependent Variable & \multirow{2}{*}{ (I) Country } & (J) Country & Mean Difference (I-J) & $\begin{array}{l}\text { Std. } \\
\text { Error }\end{array}$ & Sig. \\
\hline Knowledge-Economy Concepts & \multirow{2}{*}{ Pakistan } & UK & $-4.740^{*}$ & 1.667 & $.015^{* *}$ \\
\cline { 3 - 6 } & & India & -3.355 & 1.860 & .174 \\
\cline { 2 - 6 } & \multirow{2}{*}{ UK } & Pakistan & $4.740^{*}$ & 1.667 & $.015^{* *}$ \\
\cline { 2 - 6 } & & India & 1.386 & 2.019 & .772 \\
\cline { 2 - 6 } & \multirow{2}{*}{ India } & Pakistan & 3.355 & 1.860 & .174 \\
\cline { 3 - 6 } & & UK & -1.386 & 2.019 & .772 \\
\hline
\end{tabular}

The table indicates Tukey HSD post hoc applied for comparison among teachers' concepts in order of different countries. Findings showed a significant difference in the teachers' concepts $p=.015^{* * *}$ of Pakistan and the United Kingdom but were no difference between other states teachers' perceptions about the knowledge economy.

Table 8: Qualification Difference in Teachers' Concepts and Roles about Knowledge-Economy

\begin{tabular}{llllll}
\hline Factors & Qualification & $\boldsymbol{M}$ & $\boldsymbol{S D}$ & $\boldsymbol{F}$ & Sig. \\
\hline Knowledge-Economy Concepts & M.A/M.Sc & 52.00 & 7.942 & 4.462 & .014 \\
\cline { 2 - 6 } & M.Phil & 52.67 & 7.253 & & \\
\cline { 2 - 6 } & Ph.D. & 57.06 & 6.600 & & \\
\cline { 2 - 6 } & Total & 55.72 & 7.152 & & \\
\hline Knowledge-Economy Roles & M.A/M.Sc & 80.57 & 7.583 & .622 & .539 \\
\cline { 2 - 6 } & M.Phil & 81.67 & 10.731 & & \\
\cline { 2 - 6 } & Ph.D. & 83.45 & 9.672 & & \\
\cline { 2 - 6 } & Total & 82.78 & 9.497 & & \\
\hline
\end{tabular}

One-way ANOVA was applied to check qualification difference in teachers' concepts and roles in the knowledge economy. There was qualification difference in teachers' concepts 4.462, $p=.01$ regarding knowledge economy but was no difference in their roles .622, $p=.53$ at significance level $p \geq .05$.

Table 9: Post Hoc for Qualification Difference in Teachers' Concepts about Knowledge-Economy

\begin{tabular}{llllll}
\hline Dependent Variable & (I) Qualification & (J) Qualification & Mean Difference (I-J) & Std. Error & Sig. \\
\hline Knowledge-Economy Concepts & M.A/MSc & PhD & $-5.061^{*}$ & 2.029 & .038 \\
\hline
\end{tabular}

The Tukey HSD post hoc test was applied for comparison among teachers' concepts in order of different qualification levels. Findings showed that there was a significant difference in the teachers' concepts $p=.03$ of MA and Ph.D. degree holders, but there was no difference between other degree levels of teachers regarding knowledge economy. 


\section{DISCUSSION}

The current study was established to identify the roles and concepts about the knowledge economy of university teachers of three different states. The study focus was to explore concepts which teachers have about the knowledge economy, what they know about it firstly and secondly after that to determine their roles in this regard, how they take part and show their responsibilities to develop a knowledge economy. The findings of the study showed teachers are well aware and they know the field of the knowledge economy. They also are familiar with their roles to acquire a more knowledge economy in the 21 st century. These outcomes support past studies' results one of the latest studies explored by Awajneh, et al. (2017) in Palestine and Mohammad (2012). They directed researches related to the knowledge economy perspective of university teachers that give the challenge to stay aware of advancement and worldwide progress and improvement just to give inspiration of education field. It was discovered that instructors have experienced their roles and standards unmistakably (of the ideas) of the information economy in the accompanying zones (planning, performing educating, self-improvement, and instructions). Teachers know their roles about knowledge economy but performing moderately. They need training that how can they perform more in the context of the knowledge economy to compete in the world. It is also their vital role as researchers. Results are in an agreement with the subsequent studies; Bejinaru (2018), Hilat and Qdah (2008), Kang (2003), Shehadeh and Alomari (2014) showed the teachers 'roles were high in the knowledge economy.

Results of this research indicated that teachers are skilled-oriented and practice teaching to produce knowledge. They learn new things from books and other faculty members. The past studies uncovered similar results that the learning economy idea in the perspective of teachers was high. It was exposed that they have information about the knowledgebased economy in the significance of learning human capital and putting stock in the market. Their attention to the significance of the developed, specialized and instructive framework and the analytical research has a significant job in going into the learning economy world. They have to connect training and to make information and innovative work forms just as reasonable dissemination of human capacities, that was demonstrated by Connell (2015), Juma (2009), and Naser et al. (2016). The need for institutions' progress is to learning economy to get effective cooperation into this era. The necessity of the education sector is to adopt change towards the information and globalization age to empower the instructor to deal with the enlightening condition and challenges. It was seen that employees have advanced capabilities and aptitudes to survive in complex challenges. They realize that they require training in the field of the knowledge economy and as researchers and specialists. In this context, this study's findings supported the earlier researches (Abu Al-Humos, 2006; Lavergne, 2004; Al-Hashimi \& Al-Azawi, 2009).

\section{CONCLUSION}

The study was conducted to check knowledge economy concepts and roles in perspectives of university teachers of Asian and European states and examine the relationship between knowledge economy concepts and roles of university teachers of different countries. Knowledge oriented economy considers inventiveness to be the establishment stone where consideration is given to the idea instead of crude materials and human exertion. Teachers of three states from public and private universities participated in this study, which was a lecturer to professor. They had teaching experience from range one to more than twenty years in this profession. Human beings are considered the source of knowledge capital because they generate new knowledge with innovative ideas and conducting researches in different fields. Humans are a source of producing and placement of knowledge excellently and professionally. They utilize information and develop new technology. Technology helps out human beings to know more in less time. The economy that focuses on gaining knowledge plays the primary role to improve life quality in all areas. Teachers were strongly agreed that it develops human capitals and building sustainable development. The majority of them said they produced educated people throughout their lives. They also agreed to everything that allied to the economics of knowledge practices itself for conducting research and development activities. It is concluded that most of the teachers have clear knowledge economy concepts.

Most participants agreed they play roles in the knowledge economy effectively and show readiness in social activities. They can negotiate and discuss different topics for learning. Mean score shows they have the skills to lead the class and instruct students. They play roles by showing justice and equality characteristics. Critical thinking plays a vital role in the knowledge economy. Teachers said they practice and use critical thinking while teaching the class as well as in research activities. They treat students in a friendly environment and support them where they demand. They play a crucial role in the knowledge economy while transforming civilization's basis, norms, and moral values to the next generation. They agreed they can learn new things, emotionally intense, and disagree with others just to gain knowledge and for good researchers. They have supportive behavior with colleagues. Therefore, university teachers are playing different vital roles to produce more knowledge economy comprehensively. There is a strong statistically significant relationship between teachers' knowledge economy concepts and roles. It seems teachers have an understanding of the knowledge economy. They know the roles that they play to generate a knowledge economy. Those teachers who have knowledge economy concepts may play roles extraordinary to upgrade knowledge economy. There was a statistical difference in their concepts and roles regarding knowledge economy at significance level $p \geq .05$. It means that teachers have different perceptions regarding concepts and roles due to gender differences. Findings showed a significant difference in the teachers' conceptions of Pakistan and the United Kingdom but were no difference between other states 
teachers' perceptions about the knowledge economy. Without a knowledge economy, no one can sustain itself in the arena of history, politics, economic zone, technology, social well-being, and education. However, it is empirically investigated that knowledge economy is critical to surviving in the academic field for any nation as the monetary economy.

\section{LIMITATIONS}

It was the first multinational study in this context. However, approaching the sample of the study was a significant limitation in this situation. Teachers were contacted through an online questionnaire for data collection purposes.

\section{IMPLICATIONS}

Higher education is the backbone of society. It produces more knowledge than in school and college because more attention is given to research at the university level. As we focus research more, we can have more latest and new expertise. Thus, relevant authorities should focus on research. The teacher is the one element of the teaching-learning process. Without, this factor the education system is unable to deliver. There is a need to understand and teach precise concepts of knowledge economy among teachers. They have to clear conceptions about the information and the learning economy. Concepts understanding may help them to play their roles effectively and meritoriously to produce a knowledge economy. To better understand, seminars and workshops may be arranged in which training is provided to teachers. Their cognitive level may be sharped so that they think of innovative ideas and generate knowledge. They can enhance their skills and become specialists in a particular discipline. Administration and leadership may motivate teaching staff to play roles in the age of knowledge economy. Higher Education Commission should launch suitable programs to train teachers and improve their capacity in this paradigm.

\section{AUTHORS' CONTRIBUTION}

The authors participated by performing different contributions in this study.

Dr. Saghir Ahmad Ch. had a leading and dynamic role to conduct this study. He gave the idea and planned the study. He stated objectives, methodology, developed a questionnaire on the Likert scale, collected data and analyzed by using structural modeling, interpreted and discussed results with past studies, and concluded the study. He generated hyperlinks of citations with references. He also showed his interest in formatting and proofreading paper and finalized paper according to APA Manual 7th edition. He incorporated the editor and reviewer's comments.

Dr. Ayesha Batool focused to write the abstract introduction, and rationale of the study, generated tables during analysis, and interpreted the tables during analysis. She also contributed to formatting and gave the final shape of the paper.

Ms. Sadaf Iqbal contributed to the literature review, rephrasing the content and checked citations.

Prof. Dr. Manzoor Hussain Shah, motivated during discussion. He reviewed paper and proof read critically.

\section{REFERENCES}

1. Abu Al-Humos, N. (2006). Towards education policies to enhance competitive knowledge economy in the Palestinian areas. Palestinian Economic Policy Research Institute (MAS).

2. Abu-Nair, N. S., Al-Sarhan, K. A., Al-Zboon, M. S. (2011). The concept of knowledge economy and the roles of teachers renewable from the viewpoint of secondary teachers in Jordan and its relationship with some variables. Diarasat: Educational Sciences, 38(1), 330-343. https://journals.ju.edu.jo/D irasatEdu/article/view/2358

3. Ahmad, N. M. (2016). Insuring high education quality under knowledge community. The Sixth Arab International Conference on Insuring Education Quality, High Institution of Comprehensive Carrers, Darna, Libya.

4. Ahmad, S., \& Hussain, A. (2019). Authentication of psychosomatic capability and workplace life of teachers scales by Structural Equation Modeling. Journal of Educational Research, 22(2), 68-81. http://jer.iub.ed u.pk/journals/JER-Vol-22.No-2/6.pdf

5. Al-Hashimi, A., \& Al-Azawi, F. (2009). Knowledge economy and building the teacher. Al-Ein: University Book Center.

6. Ameen, K. (2020). Challenges of knowledge economy in Pakistan. The News International. https://www.thenews.com.pk/tns/detail/704314-challenges-of-knowledge-economy

7. Arab Knowledge Index. (2015). Mohammed bin Rashid Al Maktoum Foundation and the Regional Bureau for Arab States UNDP.

8. Awajneh, A. M. H., Sabbah, S. S. M., \& Naser, I. A. S. (2017). Concepts and roles of faculty in the Palestinian universities in the light of knowledge economy. World Journal of Education, 7(6), 80-89. https://doi.org/10.5430/wje.v7n6p80

9. Batarsah, M. (2005). Building training program based on knowledge economy competencies of professional development for teachers in Jordan, (Unpublished doctoral dissertation). Amman Arab University for Higher studies, Amman, Jordan. 
10. Bejinaru, R. (2018). Factorial analysis perspectives upon students' skills in the knowledge economy. Management Dynamics in the Knowledge Economy, 2(6), 266-286. https://www.zbw.eu/econisarchiv/bitstream/11159/3687/1/1681402890.pdf

11. Bonal, X., \& Rambla, X. (2003). Captured by the totally pedagogies Society: Teachers and teaching in the knowledge economy. Globalization, Societies and Education, 1(2), 169-184. https://doi.org/10.10 80/14767720303916

12. Brinkley, I. (2014). Defining the knowledge economy. Knowledge Economy Program Report. https://www.bl.uk/collection-items/defining-the-knowledge-economy\#

13. Connell, R. (2015). The knowledge economy and university workers. Australian Universities' Review, 57(2), 91-95. https://files.eric.ed.gov/fulltext/EJ1073612.pdf

14. Frunzaru, V., Vatamanescu, E. M., Gazzola, P., \& Bolisani, E. (2018). Challenges to higher education in the knowledge economy: anti-intellectualism, materialism and employability. Knowledge Management Research \& Practice, 16(3), 388-401. https://doi.org/10.1080/14778238.2018.1493368

15. Hashimi, A., \& Azawi, F. (2010). Knowledge economy and teacher formation. Dar Alkitab Jameei, Ein, UAE.

16. Hilat, B., \& Qdah, M. (2008). Degree of the Jordanian supervisors' possession of cognitive knowledge concepts in light of some demographic variables. Najah University Journal of Research, 22(2). https://moe.gov.jo/

17. Juma, M. S. A. A. (2009). Developing education and its role in establishing knowledge economy. Faculty of finance and administration science, Taif University. Proposal presented by the First International Conference for Electronic Learning and Distance Learning, The Kingdom of Saudi Arabia, Riyadh.

18. Kang, T. (2003). The knowledge advantage: Tracing and testing the impact of knowledge characteristic and relationship on project performance, (Digital doctoral dissertation). University of California, Los Angeles.

19. Khalaf, F. H. (2007). Knowledge economy, Alem kotob Hadeth, Amman, Jordan. Knowledge economy. Paper presented at the International conference: Rethinking English language education for today's Vietnam, Vietnam National University/ Hanoi University of Languages and International Studies

20. La Rue, B. (2005). Toward view of working, living, and learning in the knowledge economy: Implications of the new learning imperative for higher education, distributed organizations, and knowledge workers. The Fielding institute.

21. Lavergne, M. (2004). The 2003 Arab human development report: A critical approach. Arab Studies Quarterly, 26(2), 21-34. https://halshs.archives-ouvertes.fr/halshs-00638162/document

22. Krishnaswami, M. (2015). From knowledge traditional to knowledge economy: Positive interludes in Indian higher education. International Journal of Educational Planning \& Administration, 5(1), 19-23. https://www.ripublication.com/ijepa/ijepav5n1_04.pdf

23. Mohammad, D. M. (2012). The quality of high and continuing education institutions and the challenges of knowledge community. The Second Arab International Conference on Insuring Education Quality, University of Cairo, Egypt.

24. Moiseev, V. V., Karelina, M. Y., Komarova, O. A., \& Karelina, E. A. (2019). Higher education as a factor in the development of the knowledge economy in Russia. Advances in Social Science, Education and Humanities Research, 322, 7-13. https://doi.org/10.2991/iserss-19.2019.2

25. Naser, I., Awajneh, A., \& Sabbah, S. (2016). Degree of the teachers' practice of their roles and knowledge economy concepts from their perspective in Palestine. Journal of Emerging Trends in Educational Research and Policy Studies (JETERAPS, ) 7(5), 371-382. https://core.ac.uk/download/pdf/287330957.pdf

26. Oluwadare, A. J. (2015). Towards a knowledge-based economy: Challenges and opportunities for Nigeria. International Conference on African Development Issues (CU-ICADI) 2015: Social and Economic Models for Development Track. https://core.ac.uk/download/pdf/32226318.pdf

27. Safi, A., Qara, S., \& Dabor, A. (2010). Teaching the children in the era of knowledge economy. Dar Thagafa for publishing and distribution, Amman, Jordan.

28. Salem, M. I. (2014). The role of universities in building a knowledge-based economy in Saudi Arabia. International Business \& Economics Research Journal, 13(5), 1047-1056. https://doi.org/10.1903 0/iber.v13i5.8771

29. Salman, J. D. (2009). Knowledge economy. DarYazori, Amman, Jordan.

30. Shehadeh, F., \& Alomari, W. (2014). The degree of science teachers' practicing of their new roles in light of the orientations of knowledge economy competence in Jordan and its relationship to some variables. Al-Najah University Journal for Research, 28(9), 2089-2124. https://journals.najah.edu/medi a/journals/full tex ts/5 8jAYrIw.pdf

31. Thalgi, M. J. (2020). The university's role in developing the skills of the knowledge economy from the perspective of students of Yarmouk University's faculty of Shari'a and Islamic Studies. Journal of Knowledge Economy, 11, 1529-1537. https://doi.org/10.1007/s13132-019-00620-5

32. UNESCO. (2015). International report of monitoring education for all, achievements and challenges. Paris. https://en.unesco.org/gem-report/taxonomy/term/199

33. World Bank. (2008). World development indicators: Year in Review. Geneva, World Bank. https://openknowledge.worldbank.org/handle/10986/11855?locale-attribute=en 